\title{
Clinical and epidemiological aspects of epilepsy in the elderly
}

\author{
E Le Piane \\ From de Senectute: Age and Health Forum \\ Catanzaro, Italy. 5-7 December 2009
}

The concept that epilepsy is a disease of childhood and adolescence is rooted in pretty common knowledge. Actually it's not quite right as several epidemiological studies conducted in developed countries have shown that both the incidence and prevalence of epilepsy is higher among the elderly compared to other segments of the population and is growing in connection with the increase of age from 55 onwards. The incidence of epilepsy in the general population is estimated by the epidemiological study Rochester [1] in 44 cases/100.000 inhabitants per year. The same study estimated the agespecific incidence is high (82 cases) in the first year of life, decreases during childhood, remains stable and relatively low in adulthood and grows considerably from 55 : subjects aged $>75$ years showed the peak incidence (139 cases). As regards prevalence data in Rochester study [2], it is interesting to note that the cumulative rate of epilepsy in the age groups 55-64 and 65-74 year-old is around $1.5 \%$, which is the double of the previous ageranges. In the course of the "Rotterdam study", the prevalence of active epilepsy was found to be $0.7 \%$ in the age-range 55-64 and 1.2\% in the age-range 85-94 [3] As concerns the clinical and semiologic aspects, seizures of the elderly are more difficult to interpret correctly for a variety of reasons, as opposed to those of the child or young adult which are more easily recognized. This is because the elderly person often presents with other comorbid diseases and is being treated with drug therapies that have adverse side effects or may fake seizures. In the elderly partial seizures generally prevail on generalized ones with alteration of contact with the surrounding environment with or without secondary generalization. The most common underlying etiology of seizures that begin later in life is the cerebro-vascular one, followed by cancer and head trauma, metabolic

Departement of Neurology, Hospital "Pugliese-Ciaccio", Catanzaro, Italy disorders and degenerative diseases (like Alzheimer's disease).

Published: 19 May 2010

\section{References}

1. Hauser WA, Annegers JF, Kurland LT: Incidence of Epilepsy and Unprovoked Seizures in the Rochester-Minnesota: 1935-1984. Epilepsia 1993, 34:453-468.

2. Hauser WA, Annegers JF, Kurland LT: Prevalence of Epilepsy in Rochester, Minnesota: 1940-1980. Epilepsia 1991, 31:429-445.

3. De la Court A, Breteler MMB, Meinardi $\mathrm{H}$, et al: Prevalence of Epilepsy in the Elderly: The Rotterdam Study. Epilepsia 1996, 37(2):141-147.

doi:10.1186/1471-2318-10-S1-L38

Cite this article as: Le Piane: Clinical and epidemiological aspects of epilepsy in the elderly. BMC Geriatrics 2010 10(Suppl 1):L38.

Submit your next manuscript to BioMed Central and take full advantage of:

- Convenient online submission

- Thorough peer review

- No space constraints or color figure charges

- Immediate publication on acceptance

- Inclusion in PubMed, CAS, Scopus and Google Scholar

- Research which is freely available for redistribution

Submit your manuscript at www.biomedcentral.com/submit 